University of Nebraska - Lincoln

DigitalCommons@University of Nebraska - Lincoln

April 1981

\title{
Elm trees and elm leaf beetles: patterns of herbivory
}

Cliff A. Lemen

University of Nebraska-Lincoln, clemen2@unl.edu

Follow this and additional works at: https://digitalcommons.unl.edu/natrespapers

Part of the Natural Resources and Conservation Commons

Lemen, Cliff A., "Elm trees and elm leaf beetles: patterns of herbivory" (1981). Papers in Natural Resources. 31.

https://digitalcommons.unl.edu/natrespapers/31

This Article is brought to you for free and open access by the Natural Resources, School of at DigitalCommons@University of Nebraska - Lincoln. It has been accepted for inclusion in Papers in Natural Resources by an authorized administrator of DigitalCommons@University of Nebraska - Lincoln. 


\section{Elm trees and elm leaf beetles: patterns of herbivory}

\section{Cliff Lemen}

The rate of attack on elm seedlings by the Elm Leaf Beetle is affected by the seedlings position relative to adult elms. Those seedlings directly under adult trees suffer 580 times the insect attack from the beetles as seedlings not directly under adult elms. Excluding seedlings under adult elms, the number of egg masses found on an elm plant is directly proportional to its size. It was found that below a certain size seedlings were completely free from beetle attack.

Активность нападения илымового листоеда на всходы вяза зависит от расстояния от всходов до взрослых деревъев. Всходы, расположенне прямо под взрослым деревом, повреждаются в 580 раз бошые, чем те которые не находятся непосредственно под взрослым вязами. За исключением всходов, находячшхся под взросыыми деревъями, число кладок на каждом растении пропорционально его размерам. Учтановлено, что у растений меные определенной величины всходы вовсе не заражаются вредителем. 


\section{Introduction}

Janzen (1970) proposed that one mechanism operating to increase tree diversity in the tropics is insect action. He reasoned that the closer a seedling grows to an adult of its own species, the higher the probability it will be attacked by the specialized insect herbivores already exploiting the adult tree. At the seedling stage any insect damage might prove fatal to the plant, and so it would be very difficult for seedlings to establish themselves near adults of their own species. Only those seedlings which grow away from the adult trees do not receive heavy insect attack long enough to grow to a size where they can withstand some insect damage.

Such a herbivore-prey relationship would tend to increase tree diversity. Janzen (1971) was able to find some support for this model with the vine Dioclea in Costa Rica. $\mathrm{He}$ found a noctuid caterpillar specializing on the vine. The caterpillars were often common, and if they fell to the ground under the vine, they wandered in search of food. When such a caterpillar came across a vine seedling it could entirely destroy the young plant. Janzen was able to substantiate his model by showing that vine seedlings under parent plants suffered more insect damage than seedlings farther away from an adult vine.

I wanted to ascertain if the same situation could be found in the temperate zone with a different kind of insect herbivore. The system I chose to study was the Chinese Elm Ulmus parvifolia and the Elm Leaf Beetle Pyrrhalta luteola. The area of study was a single city block in Albuquerque, New Mexico in the spring of 1977. Chinese Elms and Elm Leaf Beetles, old world species, are both extremely common in Albuquerque. The Chinese Elm has been widely selected as a yard tree, and is one of the most common trees away from the river bottom habitat. Unfortunately for some home owners in the area, this tree is attacked by the Elm Leaf Beetle to the point where $50 \%$ or more leaf damage is possible. In the early spring the elms leaf out, and the Elm Leaf Beetles, dormant through the winter, lay their eggs on these new leaves. The eggs hatch and the larvae attack the elm leaves. After about four or five weeks the larvae pupate into adults. In Albuquerque, because of the rarity of other species of elm trees, Pyrrhalta luteola can be considered a specialist on Ulmus parvifolia.

\section{Materials and results}

On the block to be studied ten elm trees all taller than six meters were selected. From each of these trees four branches were picked and the number of egg masses of the Elm Leaf Beetle were counted. The volumes of these branches were found by measuring a branch's length, greatest width,

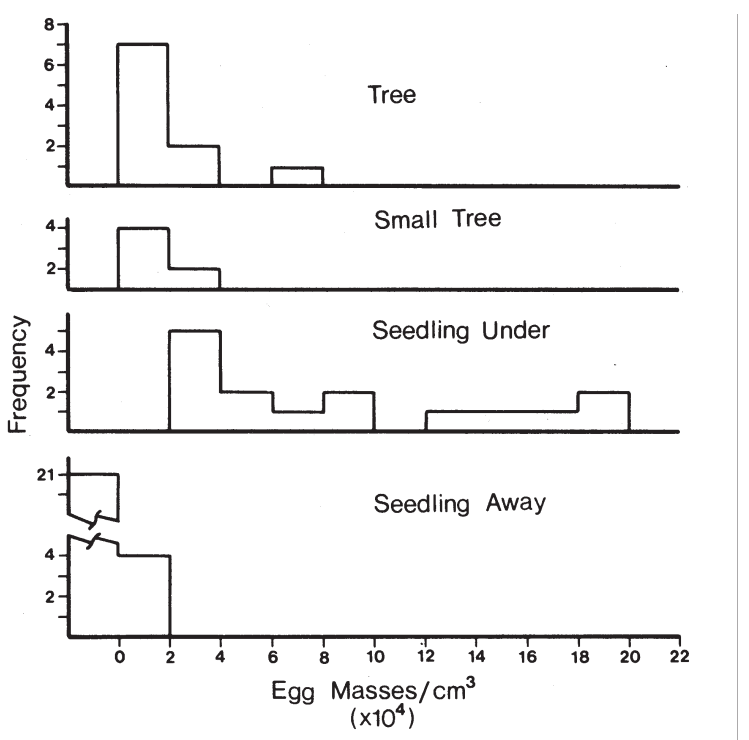

Fig. 1. Histograms showing the intensity of Elm Leaf Beetle attack on elm plants of different sizes. Intensity of attack is measured by the egg masses laid on a plant divided by the plant's volume.

and a second width at right angles to the greatest width. I also counted egg masses on elm seedlings (or suckers) and measured the volume of these plants using the same method outlined for elm branches. The seedlings were categorized into two simple groups; the seedlings that were directly under an adult elm tree and those that were not. Finally one last group was also sampled, small trees from two to six meters in height.

The results of this study can be summarized into these points:

1) The average rate of attack, as measured by egg masses per plant volume, was as follows for each group: small seedlings away from elm trees $(n=21) 0.0$ egg mass

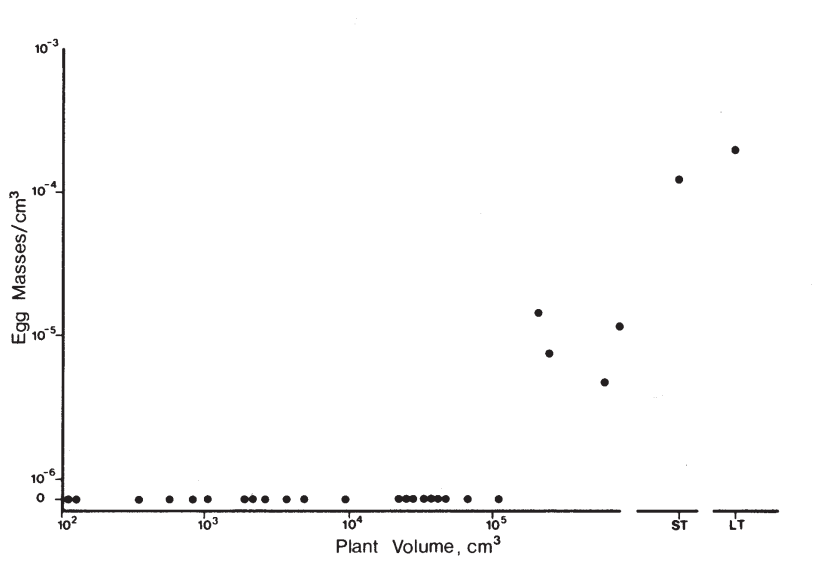

Fig. 2. Scattergram showing the relationship between intensity of insect attack and plant size for Ulmus parvifolia. The points shown for small (ST) and large (LT) trees are determined from the average intensity of attack on these groups and a relative placement on the size axis. 
es $/ \mathrm{cm}^{3}$; large seedlings away from the elm trees having volumes greater than $2.0 \times 10^{5} \mathrm{~cm}^{3}(n=4) 9.7 \times 10^{-6}$ egg masses $/ \mathrm{cm}^{3}$; small trees greater than $2 \mathrm{~m}$ and less than $6 \mathrm{~m}$ high, $(n=4) 1.3 \times 10^{-4} \mathrm{egg}$ masses $/ \mathrm{cm}^{3}$; trees greater than $6 \mathrm{~m}$ high $(n=10) 2.0 \times 10^{-4} \mathrm{egg}$ masses/ $\mathrm{cm}^{3}$; and seedlings under elm trees (all less than $2.0 \times$ $10^{5} \mathrm{~cm}^{3}$ in volume) $(n=15) 1.33 \times 10^{-3}$ egg masses/ $\mathrm{cm}^{3}$. Using the Mann-Whitney U test I found all groups were significantly different from one another $(p=0.05)$ except small and large trees (Fig. 1).

2) Small seedlings away from adult elm trees were free from Elm Leaf Beetle attack. Only after a seedling attained a volume of $2.0 \times 10^{5} \mathrm{~cm}^{3}$ were they found by the beetles (Fig. 2).

3) Seedlings directly under elm trees suffer an incredible amount of attack (Fig. 2). The average number of egg masses per volume was 852 times greater for these seedlings than for seedlings not directly under an elm tree. In fact, the rate of attack on these seedlings under trees was 6.65 times greater that the trees they were under receive.

\section{Conclusions}

Chinese Elms and Elm Leaf Beetles appear to have herbivore-prey relationships extremely similar to those found by Janzen (1971) with the vine Dioclea and a noctuid moth. In this study, small seedlings under trees suffer very high rates of insect attack, these plants being totally defoliated in a few weeks. At the same time there was only moderate leaf damage on the trees and virtually no damage on the seedlings away from the trees. The effect elm trees had on seedlings was restricted to those plants directly under their canopies, seedlings a few meters out from under the canopies were free of egg masses.

One complication pointed out to me by reviewers is that many of the small elms under adult trees are suckers and are the same genotype as the adult. It is possible that beetles have selected the tree they attack by its genotypesome trees' genotypes being more susceptible to exploitation. Unfortunately, the critical test of this hypothesis, comparing attack rates on suckers and seedlings (diverse genotypes) under trees, is not possible at this point. In spite of this, I feel the large difference in herbivory between near and far seedlings (or suckers) is predominately due to the spatial patterns of insect attacks.
As the seedlings not under adult elms grow, the number of egg masses laid on them also grows. When the plants exceed $2 \mathrm{~m}$ in height they are suffenng insect attack at approximately the same rate as the trees.

When only moderate leaf damage had occurred on the adult trees, the seedlings under these trees were completely defoliated. The larvae on these seedlings were still too small to pupate and so had to move to a new food source. Considering the small size and limited mobility of these larvae, it appeared unlikely they could successfully move to the tree's leaves. The adult females that laid the eggs on the seedlings could have easily flown the short distance between the ground and the trees leaves yet did not. This appears to be an error on the part of the Elm Leaf Beetle. Evidently these beetles are not always able to assess the food potential of the plant they lay their eggs on. This may indicate that oviposition sites are chosen on the basis of detectability alone. The first elm the beetle can find is used. Because elm trees are much larger and more detectable than seedlings most beetles are drawn to the trees. The increased rate of attack on the seedlings under trees could be caused by a ground effect similar to the one found by Janzen (1971). The beetles that accidentally fall from the tree are stopped by the ground in the general area of the seedlings. Once near the seedlings some of the beetles detect and lay eggs on them. The actual number of eggs laid on seedlings, although proportionally high, is very small as compared to the number of egg masses laid in trees. A rough calculation indicates a maximum of $0.06 \%$ of the total egg masses produced are being laid on the seedlings under trees. Such a small percentage of deaths due to the error in oviposition sites probably has no effect on the population dynamics of the beetles and it also may be insufficient to produce evolutionary change in the elm beetle population to correct the error in oviposition selection. Although the direct effects on the beetle are small, this situation does have a large effect on the seedlings directly under the elm trees.

\section{References}

Janzen, D. H. 1970. Herbivores and the number of tree species in tropical forest. Am. Nat. 104: 501-528.

1971. Escape of juvenile Dioclea megacarpa (Leguminosae) vines from predators in a deciduous tropical forest. Am. Nat. 105: 97-112. 